\title{
Anomalies: Closed-End Mutual Funds
}

\section{Citation}

Lee, Charles M. C, Andrei Shleifer, and Richard H Thaler. 1990. Anomalies: Closed-End Mutual Funds. Journal of Economic Perspectives 4, no. 4: 153-164. doi:10.1257/jep.4.4.153.

\section{Published Version}

doi:10.1257/jep.4.4.153

\section{Permanent link}

http://nrs.harvard.edu/urn-3:HUL.InstRepos:33077904

\section{Terms of Use}

This article was downloaded from Harvard University's DASH repository, and is made available under the terms and conditions applicable to Other Posted Material, as set forth at http:// nrs.harvard.edu/urn-3:HUL.InstRepos:dash.current.terms-of-use\#LAA

\section{Share Your Story}

The Harvard community has made this article openly available.

Please share how this access benefits you. Submit a story.

Accessibility 


\section{Anomalies \\ Closed-End Mutual Funds}

\section{Charles M. C. Lee, Andrei Shleifer, and Richard H. Thaler}

Economics can be distinguished from other social sciences by the belief that most (all?) behavior can be explained by assuming that agents have stable, well-defined preferences and make rational choices consistent with those preferences in markets that (eventually) clear. An empirical result qualifies as an anomaly if it is difficult to "rationalize," or if implausible assumptions are necessary to explain it within the paradigm. This column will present a series of such anomalies. Readers are invited to suggest topics for future columns by sending a note with some reference to (or better yet copies of) the relevant research. Comments on anomalies printed here are also welcome. The address is: Richard Thaler, c/o Journal of Economic Perspectives, Johnson Graduate School of Management, Malott Hall, Cornell University, Ithaca, NY 14853.

\section{Introduction}

Testing the efficient markets hypothesis is often difficult. For example, one implication of the hypothesis is that there are no free lunches, no easy ways to make money. However, apparent violations of this implication, such as mean reversion in asset prices, are said by many to be evidence of variation in risk, which is consistent with the efficient markets hypothesis. A more direct way to test the hypothesis is to compare the prices of assets to their intrinsic or

- Charles M. C. Lee is Assistant Professor of Accounting, Graduate School of Business, University of Michigan, Ann Arbor, Michigan. Andrei Shleifer is Professor of Finance, Graduate School of Business, University of Chicago, Chicago, Illinois. Richard H. Thaler is the Henrietta Johnson Louis Professor of Economics at the Johnson School of Management, Cornell University, Ithaca, New York. 
fundamental values, that is, the expected present values of future cash flows. One finance professor we know used to refer to this version of the efficient markets hypothesis as "The Price is Right!" Testing whether the price is right is hard, of course, because intrinsic values are not easily observable.

There does turn out to be one class of securities whose intrinsic values are relatively easy to measure, the so-called Closed-End Mutual Funds (now officially known as Publicly Traded Funds). Most mutual funds are open-end funds in the sense that the fund stands ready to accept more money at any time and will redeem shares for current stockholders at the "net asset value" of the fund, that is, the market value (per share) of the securities the fund holds. In the case of a closed-end fund, the management raises a certain amount of capital, say $\$ 100$ million, buys a portfolio of securities which it will manage according to its charter, and then issues a fixed number of shares, say 10 million. The shares are traded on organized stock markets, including the New York Stock Exchange. Any stockholder who wants to liquidate must sell the shares at the market price. The share price, of course, is set by supply and demand, and therefore can diverge from the net asset value. Indeed, the stock prices of closed-end funds often do diverge from net asset values. Funds selling for less than their net asset value are said to trade at a discount, while those selling for more than net asset value are said to sell at a premium. During 1989 it was possible to find some funds selling at substantial discounts (greater than 30 percent) and others selling for enormous premia (in one case over 100 percent). In the case of closed-end funds, therefore, it is common to find that the price is wrong!

\section{A Four Part Anomaly}

The pricing of closed-end funds presents several puzzles. The following are the four sets of facts that any theory of closed-end fund pricing must address.

1. New funds appear on the market at a premium and move rapidly to a discount. New funds tend to get started when the existing funds are selling at premia or small discounts (Lee, Shleifer and Thaler, forthcoming). When the new funds are released, they are sold with a commission of roughly 7 percent. This means that investors have to pay $\$ 107$ to obtain $\$ 100$ worth of assets. When they first start to trade, the funds usually trade at a small premium. However, Weiss (1989), Peavy (1988) and Laing (1987) all document striking evidence of subsequent underperformance by these new closed-end funds. Weiss (1989), for example, found that from 1985 to 1987, 20 days after the initial offering, U.S. stock funds traded at an average premium of almost 5 percent. However, 120 days after the initial offering, these funds sold for an average discount of over 10 percent. The mean daily index-adjusted cumulative return over this period was -25.1 percent ( $\mathrm{t}$-statistic of -5.55 ). So, puzzle one: Why does anyone buy these funds when they are first issued? 
2. Closed-end funds usually trade at substantial discounts relative to their net asset values. Over the period 1965-85 the (value-weighted) average discount on a portfolio of major closed-end stock funds in the U.S. was 10.1 percent (Lee, Shleifer, and Thaler, forthcoming). Though discounts are the norm, some funds (and in some unusual periods, most funds) sell at premia. In recent years, premia have been most common for funds specializing in investment in foreign countries. Puzzle two: Why aren't prices equal to net asset values, and why are discounts the norm?

3. Discounts (and premia) are subject to wide variation, both over time and across funds. The largest stock fund traded in the U.S. is the Tricontinental Fund (Tricon) which holds a diversified portfolio of common stocks. The year-end price of Tricon has varied over the last 30 years from a 2.5 percent premium to a 25 percent discount to net asset value. In 1988, the price at each week's end ranged from a 6.7 percent premium to a 17.9 percent discount. Though fund discounts vary greatly over time, their movements are positively correlated. Lee, Shleifer, and Thaler (forthcoming) studied nine of the largest and oldest funds over the period 1965-85 and found that discounts were highly correlated. Monthly levels of discounts for individual funds typically had correlation coefficients of greater than .5. Monthly changes were also positively correlated, with coefficients typically between .2 and .4. Average discounts also display a seasonal pattern which will not surprise readers of this column. Yes, discounts tend to shrink in the month of January. This result is quite striking because Brauer and Chang (1989) find that the assets the funds own do not display a January effect.

Discounts also vary widely across funds. It is common to see some funds selling for large discounts while others sell at substantial premia. Even within specific categories of funds, such as diversified domestic funds or single country foreign funds, there is wide variation in the discounts at a point in time. Puzzle three: Why do discounts move together and why do they vary so much, over time and across funds?

4. When closed-end funds are terminated, either through merger, liquidation, or conversion to an open-end fund, prices converge to reported net asset value (Brauer, 1984; Brickley and Schallheim, 1985). This fact may not seem to be a puzzle. If a fund is converted to an open-end fund, or liquidated, its assets will be redeemed at the net asset value, so of course the price should be equal to net asset value at the time of termination. However, some theories of closed-end fund pricing argue that reported net asset values are mismeasured. If this were the case, then net asset value would fall to the market price when a fund is liquidated, rather than price rising to the net asset value. When funds are open-ended, why does the price rise to eliminate the discount?

These four puzzles raise basic questions about the operation of financial markets. How can prices diverge from fundamental values? Why don't the forces of arbitrage drive prices back in line? These are the questions we will try to address in this column. 


\section{Standard Excuses}

To what extent can these facts be explained within the standard paradigm of rational efficient markets? Two types of explanations have been offered. The first is based on misbehavior by the fund managers. The second is based on miscalculation of net asset value.

\section{Agency Costs}

Might the mere existence of fund managers explain the closed-end fund puzzles? There are two possibilities worth considering. First, the funds charge a management fee, typically between .5 and 2.0 percent of the asset value annually. One argument is that the existence of these fees implies that funds will sell at a discount in equilibrium. Consider a fund with a 1 percent annual fee. At a discount rate of 10 percent, the present value of these fees corresponds to a discount of 10 percent. Upon scrutiny, however, this argument does not hold up. Large closed-end funds, such as Tricon, charge fees that are comparable to those of large no-load mutual funds. Since both are providing similar services, it would seem that both should sell at the same price. But if closed-end funds sell at a discount, investors are getting a higher yield from them than from open-end funds (since they are buying more assets for their money). The existence of fees, then, does not imply that funds should sell at discounts. ${ }^{1}$ There is also no evidence that discounts are correlated with management fees (Malkiel, 1977).

The second aspect to consider is managerial performance. Boudreaux (1973) pointed out that the net asset value represents expected returns of the present portfolio, but since fund managers buy and sell securities, discounts might reflect their differential ability to perform this task. But unless some managers have figured out a way to systematically underperform the market (itself an anomaly, of course), this explanation does not explain why funds trade, on average, at discounts. For relative performance to explain the variation in discounts, large discounts should forecast poor future performance, and premia should forecast extraordinary future returns. So, for example, the premia observed when funds start should forecast superior returns. In contrast, discounts observed a few months later suggest that investors quickly become disenchanted, and are predicting below normal performance. Logic suggests that it is impossible for both predictions to be rational, and the empirical evidence suggests that neither prediction is fulfilled. Malkiel (1977) investigated the relationship between past performance (measuring net asset value changes) and discounts and Roenfeldt and Tuttle (1973) investigated contemporaneous performance. The former found no relationship and the latter found a weak

\footnotetext{
${ }^{1}$ This argument was suggested by Ken French. Timothy Taylor has pointed out to us that one could alternatively view the fact that people are willing to invest in open-end funds without a discount as the anomaly.
} 
one. However, Lee, Shleifer, and Thaler (1990) find that future net asset value performance is weakly related to present discounts but the relationship has the "wrong" sign. That is, assets of funds with bigger discounts tend to outperform those with smaller discounts.

We conclude that agency costs cannot even explain the primary fact they are alleged to address, the existence of discounts. Agency costs do even worse on the other parts of the puzzle. For example, if agency costs are positive, then funds should never get started (at a premium) as long as no-load open-end funds exist. Indeed, a premium for any fund implies negative agency costs in this framework. Agency costs also cannot explain the wide variations of discounts over time. Neither management fees (which are extremely stable) nor expectations of performance can possibly vary enough to explain the observed time-series movement of individual fund discounts, nor the variation in the average discount across funds. The only fact consistent with agency costs is the disappearance of discounts when funds are terminated.

\section{Restricted Stocks}

A divergence between price and net asset value is not an anomaly if net asset value does not reflect the true value of the fund to the shareholders. One way in which the portfolio might be misvalued is if the fund held large quantities of stocks which cannot be freely sold in the open market. It makes sense for closed-end funds to hold illiquid stocks, since unlike open-end funds, they cannot be forced to liquidate their shares because of a sudden rash of redemptions by fundholders. Such stocks, some have argued, are valued too highly in the calculation of net asset value. In fact, both Malkiel (1977) and Lee, Shleifer, and Thaler (1990) find that restricted stock holdings can explain some portion of the cross-sectional variation in discounts.

Nevertheless, restricted stock holdings cannot explain much of the closedend fund puzzle. Most closed-end funds, including Tricon, hold little or no restricted stock and yet still sell at discounts. Also, the amount of restricted stock any given fund holds does not vary much over time, so this variable cannot explain much of the time series variability of discounts. Finally, and most fundamentally, when funds are open-ended the price rises to net asset value. If restricted holdings were overvalued, the net asset value should instead drop down to the price.

\section{Taxes}

Another reason that the true value of the fund's portfolio might be misvalued by net asset value is capital gains taxation. When a fund realizes a capital gain it must report this to the IRS. The tax liability is borne by the existing shareholders at the time the gain is realized by the fund. So if you buy a fund today and it realizes a large capital gain tomorrow, you must pay a tax even if you haven't made any money. This implies that a fund with large unrealized capital appreciation is worth less than net asset value to both 
existing and potential shareholders, and should thus sell at a discount. This explanation, like the others, has some apparent merit but fails to explain all the facts. Malkiel (1977) calculated that under fairly generous assumptions, taxes could not explain a discount of more than 6 percent. Obviously, the larger discounts that are often observed remain a mystery. Also, according to the tax story, discounts should increase when the market rises, since unrealized capital gains will be accumulating. Lee, Shleifer, and Thaler (forthcoming) present evidence counter to this implication. And, once again, the fact that prices rise to net asset values upon liquidation suggests that the tax liabilities are not major.

In summary, a number of reasons have been put forth to explain closed-end fund discounts in the context of the efficient market hypothesis and rational agents. Several of these factors do have some merit, but taken together, these factors explain only a small portion of the total variation in discounts.

\section{Closed-End Fund Premia}

Although most of the work on closed-end funds has focused on the fact that typically they sell at discounts, some of the most puzzling evidence concerns closed-end fund premia. We have already mentioned that in the mid1980s, closed-end funds went from an average 7 percent premium at the time of initial offer to an average 10 percent discount within 100 trading days. These large and rapid negative returns to initial investors raise substantial doubts about these investors' rationality. None of the standard explanations even begins to deal with the question of why anyone ever buys new issues at a premium.

Initial public offerings (IPOs) are not the only case of funds selling at premia. Historically, there have been periods when even diversified funds sold at premia, such as the late 1960s and particularly the late 1920s right before the crash. Even when the median fund sells at a discount, such as today, some funds sell at premia. These premia pose a serious challenge to agency costs, taxes and other explanations of why funds should sell at a discount.

Consider the case of the 1929 stock market boom. De Long and Shleifer (1990) find that the median fund in their sample sold at a premium of 47 percent in the third quarter of 1929, right before the crash. They also find that $\$ 1.9$ billion in closed-end funds were issued in that quarter. Adjusted for the change in the price level and the size of the U.S. economy, this amounts to roughly $\$ 55$ billion today-at least five times more than the current total outstanding value of closed-end funds. The closed-end fund boom in that summer was extraordinary, never to be repeated. The boom ended with the Great Crash, as closed-end funds moved to discounts which have remained the rule since then.

Not surprisingly, observers of closed-end funds before the Great Crash did not consider the possibility of discounts on closed-end funds. Unschooled in 
efficient markets, they reasoned that a fund's value consists of the value of its assets and the skills of its management, and so premia should be a rule. Some observers thought premia of 50 to 100 percent were reasonable (see De Long and Shleifer). During this wave of enthusiasm, theories explaining why closedend funds should sell at discounts were not advanced.

Such investor optimism about funds has not been common in recent years, with the possible exception of country funds. Some country funds (Korea, Spain, Taiwan, Brazil, and Germany) have been introduced in the mid-1980s. The new, but not the old, country funds have sold at large premia. Some of these funds such as Korea and Brazil invest in countries that restrict direct foreign investment, while others such as Germany and Spain invest in completely open markets. Both types of funds sold at large premia in the $1980 \mathrm{~s}$, sometimes above 100 percent.

What drives these country funds to a premium, especially the funds in countries with open capital markets? Those investors who drive the price of the Spain fund to an over 100 percent premium, when they could put their money in Spain directly, must be either overoptimistic about Spain (or the management of the Spain fund) or just ignorant of other ways to invest in Spain. The premia on many country funds have been gradually reduced by the entry of new country funds. In the space of a few months, three competitors each have emerged for the Spain and Germany funds. New entrants seem to trade at smaller premia than the original funds, but also to drive down the premia on the original funds. The fact that an increase in supply reduces price would not be considered anomalous in most economic markets. But in financial markets, where price is allegedly equal to value and value is independent of the supply of substitutes, this evidence is anomalous.

In sum, premia on closed-end funds seem to occur at times of great investor enthusiasm about stocks in general, such as the late 1920s or mid-1980s, or times of investor enthusiasm about particular securities, such as country stocks. These premia are very hard to fathom when investors are supposed to be cool-headed and when arbitrage should keep prices equal to values. This raises our next question: how can mispricing of closed-end funds survive arbitrage by smart investors?

\section{Money for Nothing}

If closed-end funds are so clearly mispriced, can't a smart investor make money? Consider funds selling at premia. Why can't a smart investor sell them short, and buy their portfolio, or something close to their portfolio, as a hedge? One argument usually given is that for funds investing in countries with restricted markets, one cannot buy stocks directly so the hedge is not possible. However, this is not very persuasive. Why can't a family with some members in Korea and some in the U.S. have its American branch sell short the fund and 
the Korean branch buy its portfolio? Besides, a lot of funds from unrestricted countries, such as Spain and Germany, have sold at large premia.

The problems with arbitrage turn out to lie right here in the United States. First, borrowing shares is often very difficult, so one can't sell the funds short. This has been the case with closed-end fund IPO's, as well as with many country funds recently, whether from restricted or from unrestricted markets. Even if an investor could sell them short, the proceeds are not received immediately, ${ }^{2}$ raising the cost of this trade. Second, even if an investor manages to sell a fund short and buy its portfolio, the premium can get larger before it gets smaller, leading to a capital loss on the position and the demand by the broker for more funds. If you shorted the Spain fund at a 20 percent premium, you might be broke as the premium rose to 100 percent. Unless the investor is very patient and has deep pockets, this arbitrage trade would not pay.

What about the more typical case of funds selling at discounts? In this case, the first obvious way to make money is to take the fund over and liquidate or open end it. While this is a good idea in theory, in practice there are multiple obstacles to taking over a closed-end fund. Fund managers fiercely resist takeovers, raising the bidder's costs. Herzfeld (1980) reports that by 1980 Lehman and Tricontinental - the two largest diversified funds-had each defeated four attempts to reorganize them. In the past decade, many new funds have explicitly enacted anti-takeover provisions. If the anti-takeover provisions do not work, the managers can count on the help of the SEC, which regulates investment companies and has frequently contributed to raising bidders' costs.

Even if bidders can circumvent this resistance, they must remember the lesson of Grossman and Hart (1980). Unless the bid is at net asset value, shareholders of the fund have an incentive not to tender, to wait for open ending, and then to realize the full net asset value. But if the bid is for full net asset value, there is nothing left for the bidder. Not surprisingly, the bids that succeed are typically for 95 to 98 percent of net asset value. Taking over closed-end funds is not as good a deal as it looks, which explains why so many of them selling at large discounts are still around.

A more passive strategy for a discounted fund is to buy the fund and to sell short its portfolio, which to some extent is possible (Herzfeld, 1980). But here again one runs into the costs of only partial proceeds from short sale, as well as the risk that the discount will widen, bringing a loss to a smart investor with a short horizon.

Clearly, the more obvious "easy money" strategies are not without costs and risks. Nevertheless, there is some evidence that excess risk-adjusted returns can be had by trading on closed-end fund discounts. These strategies are based on the observation that discounts are mean-reverting. This suggests buying the funds with the largest discounts, hoping they will shrink over time. Thompson

\footnotetext{
${ }^{2}$ An investor's proceeds on short sales are only paid, net of costs, when the position is closed. The credit position created by the short sale typically earns no interest for the investor.
} 
(1978) investigated the profitability of buying a portfolio of funds at discount where the amount of each fund purchased was proportional to the discount. He found that over his 32-year sample period, the strategy earned an annual excess return of more than 4 percent. ${ }^{3}$ Brauer (1988) improves on this strategy somewhat by incorporating variables which are related to the probability that a fund will be open-ended. His strategy earns an abnormal return of 5 percent a year. Anderson (1986), studying the 1965-1984 period, also finds significant excess returns to closed-end fund investments. Thus, a long-run bet on funds with high discounts appears to offer some opportunities for excess returns.

\section{Investor Sentiment-A Possible Solution to the Puzzles}

De Long, Shleifer, Summers, and Waldmann (1990) and Lee, Shleifer, and Thaler (forthcoming) have explored one possible explanation of the closed-end fund puzzle based on a model of noise traders. Here we can only give a skeleton of the argument; a somewhat fuller version is also given in Shleifer and Summers (1990).

Delong, Shleifer, Summers and Waldmann (1990) present a model with two kinds of investors: rational traders and noise traders, who make their investment decisions partly on irrational factors. The rational investors have unbiased expectations, whereas the noise traders make systematic forecasting errors. Put differently, noise trader sentiment shifts over time: sometimes they are excessively optimistic about the future, other times they are excessively pessimistic. This variability in noise trader sentiment creates a new source of risk in the markets where they trade. A final assumption is that the rational traders are risk averse, and have finite horizons, two characteristics that seem to describe most investors, even (or maybe especially) those who manage other people's money. As a result, the risk from shifting noise trader sentiment deters rational investors from attempting aggressive arbitrage strategies.

Closed-end funds are a good illustration of how the model works. Suppose there is a higher concentration of noise traders in the ownership of closed-end funds than in the ownership of the funds' assets. When noise traders become pessimistic about the future, they drive down the price of closed-end funds below net asset value. Why don't rational traders buy the funds up at the bargain prices? The answer is that in buying a closed-end fund, even at a discount, a rational trader must bear two kinds of risk. The first is that the net asset value of the fund will underperform the market. The second risk is that when the rational trader wishes to sell the fund the discount may have widened, because noise traders have become even more pessimistic. This

${ }^{3}$ As we indicated at the beginning, one problem with findings such as Thompson's (1978) is that they are conditional on the pricing model being able to measure risk properly. In his conclusion, Thompson cautions that his findings are only inconsistent with the joint hypothesis of market efficiency and a well-specified pricing model. 
analysis implies that rational investors will only be willing to buy closed-end funds if they are compensated for the noise-trader risk, that is, if they can buy the funds at a discount! This is the noise trader explanation for the most salient fact about closed-end funds, that, on average, the funds sell at discounts from net asset value. It should be stressed that this explanation does not rely on the average pessimism of noise traders; it stems completely from the risk aversion of the rational investors. Interestingly, Martin Zweig (1973) also stressed the role of investor sentiment in closed-end fund pricing, and has since started two closed-end funds that bear his name.

What about the other parts of the closed-end fund puzzle? To explain why investors buy funds initially at a premium one needs to have noise traders, or "suckers," who are sufficiently optimistic to buy overpriced assets. It helps to have a gimmick. Some recent start-ups, such as the Zweig funds, are run by famous portfolio managers; other new funds, such as the country funds, feature specialized investment strategies. Start-ups of generic diversified closed-end funds are rare, except during bubble periods such as 1929. The people who buy the new funds when issued are those most optimistic about the fund's future returns. When they subsequently try to sell their shares to other, possibly rational investors, the price falls. The fact that new funds start when existing funds are selling at premia or small discounts is also consistent with the theory. These are times when investor sentiment is high.

The facts that discounts vary over time and move together are necessary to this theory. Discounts must vary, else there would not be any risk associated with their changes. That they move together reinforces the view that discounts are a measure of investor sentiment. The fact that discounts disappear when funds are liquidated or open-ended also fits, since when either of these events happen, noise trader risk is eliminated.

The noise trader model makes several additional predictions which are tested in Lee, Shleifer, and Thaler (forthcoming). Specifically, closed-end funds are taken to be a measure of a particular type of noise trader sentiment, namely, the sentiment of individual investors. Closed-end funds are held almost entirely by individuals, rather than institutions, in part because institutions have a hard time explaining to their clients why they are subcontracting some of the money and thus imposing two management fees. The model implies that for a type of noise trader risk to be priced, it must affect other types of assets, otherwise it would be diversifiable. In this case, the logical place to look is other markets in which individuals are the predominant investors. One such market is small capitalization stocks. The investor sentiment theory predicts that when individual investors are pessimistic about closed-end funds, widening the discount, they will also be pessimistic about small firms, driving down their returns. This prediction is borne out by the data. For the period 1965-85 we studied monthly returns for each of ten portfolios of New York Stock Exchange firms, where the portfolios are formed by ranking the firms by market value of 
equity. The smallest 10 percent of the firms are in the first decile portfolio, and so forth. Each of these decile returns was regressed on the return on the value-weighted NYSE index, and the change in a value-weighted index of closed-end fund discounts. We find that the returns are significantly related to the change in the value-weighted discount for every decile. The nine smaller deciles are negatively related-when discounts fall stock prices go up. However, the relationship declines in magnitude and significance as size increases. For the largest decile, the relationship is reversed. Discounts do seem to reflect the sentiment of individual investors.

\section{Commentary}

In his seminal book on security analysis Intelligent Investor, Benjamin Graham (1985, p. 242) called the discounts on closed-end funds "an expensive monument erected to the inertia and stupidity of stockholders." Burton Malkiel (1977, p. 857), another well-known observer of financial markets, concluded his analysis of closed-end funds with the observation that "market psychology has an important bearing on the level and structure of discounts." How can stockholder stupidity or market psychology matter? In an efficient market, arbitrageurs buy and sell securities to assure that prices cannot diverge from their intrinsic values. If some investors prefer ounces of gold purchased in London to those purchased in Chicago, their preferences will not drive up the price of gold in London since other investors will be happy to buy in Chicago and sell in London. This analysis does not apply to closed-end funds. As discussed above, mispricing can occur because no riskless arbitrage opportunity exists, and the supply of rational investors willing to make long-term bets against the prevailing investor sentiment is limited. ${ }^{4}$

The major lesson we take from this analysis is that the demand for securities can influence price, even if that demand is based on irrational beliefs. In situations when this analysis applies, which includes many of the most interesting financial markets, it is important to remember that the statement "price is equal to intrinsic value" is a testable proposition, not an axiom.

We wish to thank Timothy Taylor and Thomas Russell for helpful suggestions and comments. Financial support is gratefully acknowledged from the Social Science and Humanities Research Council of Canada, the Institute of Chartered Accountants of Ontario, the Deloitte, Haskins and Sells Foundation (Lee) and Concord Capital Management (Thaler).

${ }^{4}$ See Russell and Thaler (1985) and Shleifer and Summers (1990) for more details on the limits of arbitrage. 


\section{References}

Anderson, S. C., "Closed-end Funds Versus Market Efficiency," Journal of Portfolio Management, Fall 1986, 13, 63-65.

Boudreaux, K. J., "Discounts and Premiums on Closed-end Mutual Funds: A Study in Valuation," Journal of Finance, May 1973, 28, 515-522.

Brauer, Gregory A., "Open-ending Closedend Funds," Journal of Financial Economics, 1984, 13, 491-507.

Brauer, Gregory A., "Closed-End Fund Shares' Abnormal Returns and the Information Content of Discounts and Premiums," Journal of Finance, March 1988.

Brauer, Gregory A., and Eric Chang, "Return Seasonality in Stocks and Their Underlying Assets: Tax Loss Selling Versus Information Explanations," working paper, University of Washington and University of Maryland, 1989.

Brickley, James A., and James S. Schallheim, "Lifting the Lid on Closed-end Investment Companies: A Case of Abnormal Returns," Journal of Financial and Quantitative Analysis, March 1985, 20, 107-117.

De Long, J. Bradford, and Andrei Shleifer, "The Bubble of 1929: Evidence from ClosedEnd Funds," unpublished manuscript, University of Chicago, June 1990.

De Long, J. B., A. Shleifer, L. H. Summers, and R. J. Waldmann, "Noise Trader Risk in Financial Markets," Journal of Political Economy, August, 1990.

Graham, Benjamin, Intelligent Investor, 4th revised edition. New York: Harper and Row, 1985.

Grossman, Sanford J., and Oliver D. Hart, "Takeover Bids, the Free-rider Problem, and the Theory of the Corporation," Bell Journal of Economics and Management Science, Spring 1980, p. 42-64.

Herzfeld, Thomas J., The Investor's Guide to Closed-end Funds. New York: McGraw-Hill, 1980.

Kleidon, Allan W., "Anomalies in Financial Economics," Journal of Business, Supplement, October 1986, 59, 469-499.

Laing, Johnathan R., “Burnt Offerings: Closed-end Funds Bring No Blessings to Shareholders," Barron's, August 10, 1987, pp. 6-7, 32-36.
Lee, Charles, Andrei Shleifer, and Richard Thaler, "Investor Sentiment and the Closedend Fund Puzzle," Journal of Finance, forthcoming.

Lee, Charles, Andrei Shleifer, and Richard Thaler, "Explaining Closed-end Fund Discounts-A Cross-Examination of the Evidence," unpublished manuscript, Cornell University and University of Chicago, July, 1990.

Malkiel, Burton G., "The Valuation of Closed-end Investment Company Shares," Journal of Finance, June 1977, 32, 847-859.

Marsh, T. A., and R. C. Merton, "Dividend Variability and Variance Bounds Tests for the Rationality of Stock Market Prices," American Economic Review, June 1986, 76, 483-498.

Peavy, John W., "Closed-end Fund New Issues: Pricing and Aftermarket Trading Considerations," Working Paper 88-8, CSFIM, Southern Methodist University, 1988.

Roenfeldt, Rodney L., and Donald L. Tuttle, "An Examination of the Discounts and Premiums of Closed-end Investment Companies," Journal of Business Research, Fall 1973, 1, 129-140.

Russell, Thomas, and Richard H. Thaler, "The Relevance of Quasi Rationality in Competitive Markets," American Economic Review, December 1985, 75, 1071-1082.

Shiller, Robert J., “Do Stock Prices Move Too Much to be Justified by Subsequent Changes in Dividends?" American Economic Review, June 1981, 71, 421-436.

Shleifer, Andrei, and Lawrence $H$. Summers, "The Noise Trader Approach to Finance," Journal of Economic Perspectives, Spring 1990, 4, 19-34.

Thompson, Rex, "The Information Content of Discounts and Premiums on Closedend Fund Shares," Journal of Financial Economics, 1978, 6, 151-186.

Weisenberger, A., Investment Companies Services. New York: Warren, Gorham and Lamont, 1960-1986.

Weiss, Kathleen, "The Post-Offering Price Performance of Closed-End Funds," Financial Management, Autumn 1989, 57-67.

Zweig, Martin E., "An Investor Expectations Stock Price Predictive Model Using Closed-end Fund Premiums," Journal of Finance, 1973, 28, 67-87. 